The Evolution of IBP. (International Biological Programme 1.) Edited by E. B. Worthington. Pp. $x x+268$. (Cambridge University: Cambridge, London, New York and Melbourne, September, 1975.) £10.50. Food Protein Sources. (International Biological Programme 4.) Edited by N. W. Pirie. Pp. $x x+260$. (Cambridge University: Cambridge, London, New York and Melbourne, September 1975.) $£ 7.50$.

IN March 1959, shortly after the International Geophysical year ended, Sir Rudolph Peters conceived the idea of its biological equivalent. The idea gained the support of a number of biologists, although each had a different idea of what should be studied. In this way the International Biological Programme (IBP) was born. Through the efforts of the late Professor C. $\mathrm{H}$. Waddington and Professor Guiseppe Montalenti, it had by 1964 grown into a decade long, seven-sided study of production ecology and human biology, entitled "The biological basis of productivity and human welfare." Now, nearly 20 years after its conception, the results are to be gathered in an 'international synthesis', a series of volumes of which Dr Worthington's kaliedoscopic study The Evolution of IBP is the first.

Dr Worthington was the scientific director of IBP, and the grasp of all its aspects which he demonstrates in this book, shows why Professor Waddington was so determined he should be appointed to that post. $\mathrm{He}$ modestly describes himself as editor of the book, although he is virtually its author and, as such, does an extremely workmanlike job of describing what IBP was. But for all its assiduous and dispassionate detail, Dr Worthington's book is not a history of IBP but a historical gazeteer, circumscribed by its own objectivity.

I suspect this has arisen paradoxically from Dr Worthington's deep involvement with the programme, for those so caught up in events are often the worst historians. Though Dr Worthington avoided producing an apologia for IBP he has not produced a critique either. $\mathrm{He}$ has simply chosen to record, rather than interpret, events. It is not that he sees history from the IBP's viewpoint: apart from IBP, he does not seem to see history at all. And so the events that have altered scientists' attitudes while IBP existed-events that must have moulded and been moulded by IBP - are avoided, or only mentioned coyly. Dr Worthington's book is interesting and readable but IBP still needs its Margaret Gowing.

As does the topic to which Mr Pirie has addessed himself for the past 40 years - the need for increasing world protein production. $\mathrm{Mr}$ Pirie has long been the advocate of leaf protein as one method of bridging the world protein 'gap' and he persuaded IBP to stress leaf protein in one of its themes.

\section{International biological programme}

Unfortunately, over the years the protein gap has not so much been bridged as obliterated by systematic reductions in estimates of human protein requirements. $\mathrm{Mr}$ Pirie has not appreciated this alteration. Discussing the matter in 1969 he commented on the technical competance and professional integrity of some of those responsible for these estimates suggesting that they were biased by a desire to avoid change and a wish to resist wage demands based on the cost of food.

In this volume he avoids those issues and states simply that "more research is needed to meet the world's...... protein need than.....the equally important need for energy and vitamins". I do not believe it and suspect that $\mathrm{Mr}$ Pirie underestimates the inertia of his own ideas.

The definition of a protein source used in this book (at least $15 \%$ protein on a dry weight basis) is unfortunate, since it excludes the cereals, which provide over half the protein in most diets. Further complications are introduced by the exclusion of domesticated livestock and the inclusion of coconuts and minor seeds which contain less than $15 \%$ protein, but which are "interesting and liable to be overlooked".

The discussion of nutritive value is concentrated on protein value, and is confused by the use of terms like BV, NPU and PER without definition or details of the assay conditions. It is a pity that the IBP committee on units symbols and definitions which produced the 50 page appendix to Dr Worthington's book omitted these. One suspects that some authors did not even consult IBP's own symposium on the evaluation of protein products.

Parts of the book are good-Sir Kenneth Blaxter on non-domesticated ruminants, for example-but on the whole it is a patchy compendium of some information on some aspects of some foods.

The power of the protein myth is such that its title assures it of a good sale, but $\mathrm{I}$ wish that $\mathrm{Mr}$ Pirie had devoted his talents and his time to a book on food and not fashion.

Fashion is perhaps the nub of it. It is inconceivable that an IBP started now would give such a high priority to protein. Nor that it would so easily dismiss Margaret Mead's plea for basing its Human Adaptability Programme on the social sciences. But then would a new IBP have such difficulty in getting a programme of production ecology started and funded?

IBP was overtaken by events, as anything started in 1959 had to be. In 1959 there was Eisenhower and Kruschev. No one had heard of Yuri Gagarin, and very few of James Watson. Ecology was still about beetles.

IBP's operational decade encompassed Biafra and Vietnam. At its end there were famines in the Sahel and Ethiopia. A study of the biological bases of human welfare conceived now would be very different indeed: IBP seems academic, old fashioned and even slightly naïve.

Some of its synthesis volumes-the academic ones-will no doubt be standard texts, as some of its achievements are undeniable. Those like $\mathrm{Mr}$ Pirie's that are concerned so directly with human welfare run the risk of being outdated by the time they appear. Whether in the long run they'll be seen as the more significant or noble, remains to be seen.

John Rivers

Crop Genetic Resources for Today and Tomorrow. International Biological Programme 2.) Edited by O. H. Frankel and J. G. Hawkes. Pp. xiv +491 . (Cambridge University: Cambridge, London, New York and Melbourne, September 1975.) $£ 13$.

IN recent years there has been an increasing awareness of the erosion of plant genetic resources due to the extension and intersification of land 